\title{
Impact of Water Reallocation on the Economy in the Fertile Crescent
}

\author{
Tala Qtaishat
}

Received: 19 December 2011 / Accepted: 3 June 2013 /

Published online: 26 June 2013

C The Author(s) 2013. This article is published with open access at Springerlink.com

\begin{abstract}
Water scarcity is a societal problem in arid and semi-arid regions in the Fertile Crescent (FC). In FC countries, water shortages threaten economic growth, social cohesion, environmental sustainability and political stability. Under drought conditions, water shortages can be mitigated by using water more efficiently and by appropriate allocation of scarce water resources. In this paper water reallocation is addressed by reallocating some agricultural water use for other higher-value uses such as municipal and industrial sectors. Reallocating water from irrigation to other uses can provide sufficient and sustainable water supplies to meet the growing domestic and industrial demands for the next two decades. Most of the literature on water reallocation suggests that shifting water use from agriculture to other sectors would be feasible, but few studies address how much water should be reallocated.. The conceptual model will suppose that there are two users (A and $\mathrm{B}$ ) and that their economic efficiency can be achieved when $\mathrm{MB}_{\mathrm{A}}=\mathrm{MB}_{\mathrm{B}}$, ceteris paribus. A reallocation of water away from agriculture at $1 \%$ of average total water use per year for the next 20 years for a total reallocation of $20 \%$ by year 20. would increase GDP, could help alleviate the water-scarcity problem in the FC and lead to more efficient use of water. Further work or modeling is less important than is action based on available analyses. All evidence suggests decision-makers would be on solid ground to began re-allocating water in the FC now.
\end{abstract}

Keywords Water scarcity · Fertile Crescent (FC) · Water reallocation and GDP

\section{Introduction}

Worldwide, more than a billion people do not have clean drinking water, and about half of the world's population in 80 countries suffers from serious water shortages (United Nations

T. Qtaishat $(\bowtie)$

Agriculture College, Agricultural Economics and Agribusiness Department, The University of Jordan, Amman 11942, Jordan

e-mail: talaqtaishat@yahoo.com

T. Qtaishat

e-mail: t.Qtaishat@ju.edu.jo 
Environment Program UNEP 2002). The FC countries of Jordan, Iraq, Syria, Lebanon, Israel and the Palestinian Territories (West Bank+Gaza Strip) face some of the most severe water shortages in the world. Population growth, economic development, higher standards of living, increased water use for agriculture and declining rainfall in the region have each contributed to water shortages (United Nations Environment Program UNEP 2002).

Since the 1910s, most policy-makers and researchers have considered the scarcity of water and its effects on both developing and developed countries as a global threat (Bontemps and Couture 2002). Water shortages restrict economic development, impact urban industries and may affect the environment (United Nations 2003).

Water use in the FC falls into three categories: municipal consumption, industrial production and agricultural production (including livestock). Per capita municipal water demand in the FC has increased with growing urbanization and rising incomes (Allan 2001). Most of the FC policy-makers agree that water for human consumption, including drinking, cooking, bathing and cleaning, should be given priority over other uses.

Currently the agriculture sector consumes a majority of water resources in the FC. About $66 \%$ of the total water in the FC is used for irrigation, although water for agriculture varies from country to country. About $34 \%$ of total water resources are used in the industrial and domestic sectors, $8 \%$ and $26 \%$, respectively. Water reallocation strategies such as changing cropping patterns and moving away from crops where the product value per unit of water is relatively low could improve the overall economy. Water reallocation could have a substantial impact on the municipal and industrial sectors, and might lead to an increase in GDP for the region and create jobs in the industrial sector. A small water reallocation (5\%) from agriculture could dramatically increase water available to other sectors, particularly in the municipal sector. If the FC seeks to achieve sustained economic growth and improved social and environmental conditions, changes in how water resources are allocated and managed are required (Richards 2001).

\section{Water Uses in FC}

More than half of the countries in the FC are ranked in the world's lowest $10 \%$ of annual, per capita total renewable water resource availability (Table 1). Iraq has the greatest supply of total annual renewable water resources per capita with nearly 3.3 MCM/cap/year (Table 1). Palestine has the least total annual renewable water resources per capita in the FC with only 52,000 $\mathrm{MCM} / \mathrm{cap} / \mathrm{year}$. Jordan and Israel also have less than a million MCM/cap/year in renewable water resources. Lebanon and Syria have 1.2 and 1.6 MCM/cap/year, respectively. Lebanon has the greatest internal renewable water resources in the region with more than $1.2 \mathrm{MCM} / \mathrm{year}$. The surface water and groundwater together are about 146,600 MCM/year, which means that the water situation in Lebanon is better than the other FC courtiers. The Palestinian Territories have the least internal renewable water resources at $500 \mathrm{MCM} / \mathrm{year}$.

\section{Allocation Mechanisms}

Water allocation can be more complicated than allocation of other economic goods because water has exceptional characteristics. For example, water has few substitutes, supplies range from excess to scarce, water is a common property resource, and water is bulky and not inexpensively stored or transported. These characteristics make water allocation somewhat problematic, although many allocation tools have been developed (Tsur and Dinar 1997; Boggess et al. 1993; Kaiser and McFarland 1997; and Brill et al. 1997). 
Table 1 Water availability in the FC

\begin{tabular}{lccccc}
\hline Country & Ranking $^{*}$ & $\begin{array}{l}\text { Total renewable } \\
\text { water resources } \\
\text { (MCM/cap/year) }\end{array}$ & $\begin{array}{l}\text { Total internal } \\
\text { renewable water } \\
\text { resources } \\
\text { (MCM/year) }\end{array}$ & $\begin{array}{l}\text { Surface water: } \\
\text { Produced } \\
\text { internally } \\
\text { (MCM/year) }\end{array}$ & $\begin{array}{l}\text { Groundwater: } \\
\text { produced } \\
\text { internally } \\
\text { (MCM/year) }\end{array}$ \\
\hline Palestinian Territories & 179 & 52,000 & 500 & 0,00 & 500 \\
Jordan & 170 & 179,000 & 680 & 400 & 500 \\
Israel & 167 & 276,000 & 750 & 250 & 500 \\
Lebanon & 149 & $1,261,000$ & 128,500 & 97,300 & 49,300 \\
Syria & 141 & $1,622,000$ & 7,000 & 4,800 & 4,200 \\
Iraq & 108 & $3,287,000$ & 35,200 & 34,000 & 1,200 \\
\hline
\end{tabular}

Adapted from world water development report (World Water Development Report WWDR 2003)

* Rank of FC countries among 182 countries according to their annual, per capita total renewable water resource availability from the least (182) to the most (1)

Marginal cost pricing (MCP), water allocation via government policy, water markets and user-based allocation are examples of water-allocation mechanisms. However, no one allocation tool is appropriate for all applications or situations.

\subsection{Marginal Cost Pricing (MCP)}

MCP equates the price of water with the cost for supplying the last (i.e., marginal) unit of water. Economic efficiency, that is optimal allocation of water resources, will be achieved when the marginal value of water is equal to its marginal cost. However, water also has scarcity value that might not always be reflected in the cost that consumers pay or in MCP (Tietenberg 1988; Spulber and Sabbaghi 1994). MCP also has to incorporate the fact that there are different prices for different quantities (e.g., block-rate pricing) or qualities of water. For example, higher-quality water has a higher marginal cost of provision (Spulber and Sabbaghi 1994). The use of water pricing as an appropriate allocation tool continues to be widely debated among economists (Dinar 2000).

\subsection{Public Allocation}

Because of public good characteristics of water, allocation by government policy is appropriate in water resource management, especially in large-scale systems. Public allocation of water resources can support food security and public health and can enable strong oversight mechanisms such as regulations to decrease water pollution. Public allocation however relies on the political powers of affected stakeholders.

The fee structures for water use under pubic allocation often do not create incentives for the users themselves to save water and use it more efficiently. The vast majority of irrigation systems, and even many domestic water supply systems, charge a flat rate per hectare or household served. Under this type of fee, not only do the users not pay according to the amount of water consumed by that land or that household, but increasing the water charges - a simplistic solution too often suggested to improve water use efficiency - can even have a perverse effect of increasing water consumption as people feel that they are entitled to more water because they are paying more.

Governments can fail to efficiently allocate water and to manage water resources effectively. Public allocation can fail because multiple agencies control many agendas which may lead to poor performance of government-operated irrigation systems, leaking municipal water supply 
systems controlled by public utilities, licensing irregularities and a lack of regulations to control industrial water use.

\subsection{Market Allocation}

Allocation using free market forces encourages users to find the highest-value applications for scarce water resources. Market allocations require well-defined, quantifiable and transferable property rights. Government plays an important role by monitoring, regulating and providing legal support to a functioning market. Market allocation may not lead to water use equity because some users may be unable to compete in the market. Third-party (externality) and market failures can also limit the effectiveness of market allocation. For example, transfer of water from agriculture to urban use may reduce return flows to streams, which may affect a third party (i.e., transfer of water from agriculture to urban use can affect farmers or producers). Water allocation using market-based mechanisms may require some form of institutional support to manage externalities.

\subsection{User-Based Allocation}

User-based allocations are more frequently used in small-scale systems, and are more flexible than bureaucracy-laden public allocation. Farmer-managed irrigation systems are good examples of user-based water allocation. Because those directly involved in water useeither for agriculture, households, or industry-have more information on local conditions than the government, they do not have to rely on strict formulas for allocation (Sadeque and Turnquist 1995). User-based water allocation may require institutional (government) support to encourage socially optimal decisions about water (Yoder 1981).

\section{Water Reallocation Experience in the FC}

The literature provides plentiful examples of the effects of water allocation in the $\mathrm{FC}$, as well as how re-allocation might affect aggregate productivity by sector. These published examples are the basis for encouraging use of the marginal benefits rule later in this paper.

Current water allocation in the FC has resulted in wide variation in the marginal benefits of water within and between sectors (Abu-Sharar and Battikhi 2002). Returns from irrigation within the agricultural sector vary (Bakker 1999). Industrial and municipal sector returns also vary (Beaumont 2000). Each cubic meter of water used in the industrial and service sectors produces at least 200 times more wealth than most water used in the agricultural sector (Beaumont 2000). Water reallocation in the FC could bring about an increase in the total water benefits and an increase in overall social well-being.

Household demand for water in the FC is increasing. The demands of industry will grow as the FC countries industrialize. The marginal value of water is at least ten times higher for municipal uses than for agricultural uses (Bhattia et al. 1995). A $5 \%$ reduction in water use for agriculture in Jordan could increase the municipal sector's share of water by almost $15 \%$ (Berkoff 1994). Reallocating water to domestic consumption will benefit domestic consumers and increase per capita availability by 150 cubic meters/year. The net present value of the benefit for domestic water use by the end of year 20 would amount to US\$69 per cubic meter of water at a discount rate of $15 \%$ (Dudu and Chumi 2008).

Reallocating water away from agriculture in Jordan would initially cause revenues in the agricultural sector to drop because farmers will be coping with a reduction in water supply 
and investing in new technologies (Dudu and Chumi 2008). In subsequent years, their revenues will rise at an accelerated rate until peaking in year 10. Under these conditions, water used for agricultural production will still be profitable, and the net present value will be about US\$2.6 per cubic meter of water by year 20 .

Reallocating water from the agricultural sector to the industrial sector would also be beneficial to national development. The net present value at the end of year 20 would be US\$53 per cubic meter of water at a discount rate of $15 \%$. Negative returns for the agricultural industry would only be recorded in year 1, as a result of required investment to find alternate water supply (Dudu and Chumi 2008).

\section{Constraints to Water Reallocation}

There is a vast body of literature, mostly in economics, which addresses water-scarcity problems. While the literature identifies and characterizes the FC's water problems, it fails to provide sufficient detail and data for decision-makers. Linear programming models, social planner allocations, system dynamics models, economic-engineering optimization models, safe yield concepts, mixed-quota policy and mathematical models all address narrow aspects of the issue, but do not further integrate into a straightforward, comprehensive approach which is useful to policy-makers. Natural resources managers face the complex challenge of reallocating water taking into consideration economic, cultural, social and political interrelationships. Furthermore, little research has examined both micro and macro policy interventions for improving water allocation. Many studies attempt to resolve water-allocation issues and find solutions for the constraints based on market-based solutions.

Cultural, political, environmental and fiscal constraints make allocation of water in the FC more difficult than the theories based on simplified models suggest. Following are some of the most commonly recognized constraints which affect allocation of water in the FC:

1. Efficiency constraints: Efficiency is achieved when the marginal value of water among competing uses is equal. In the real world it is difficult to discover, much less equate, marginal values.

2. Transformation: There is a transformation process to convert untreated water to treated water, for example, treating wastewater for use in the agricultural sector. Water losses are associated with transformations; rarely $100 \%$ of water is retained during transformation processes (Mahan et al. 2002).

3. Incomplete information: Water prices are an important part of the efficiency principle. In some countries, lack of information limits the market's ability to set a permanent price for water. One of the conditions for market competition is setting a rational water price. Decision-makers have to be able to find information about prices and cost-saving innovations in water projects. Moreover, they have to be able to learn about profitable opportunities in other water industries. Incomplete information will mislead decision-makers.

4. Institutional constraints: There are formal constraints (e.g., rules, laws or constitutions) and informal constraints (e.g., norms of behavior, conventions or self-imposed codes of conduct) that limit the efficient allocation of water resources (North 1994). For example, in FC countries, lack of government regulation often results in both third-party effects and externalities.

5. Financial constraints: Considerable investment in water development infrastructure will be needed to meet future water needs. Policy-makers need to consider the fiscal implications of such large investments. 
6. Resource overexploitation: Overexploitation of water resources in FC countries, such as overuse of aquifers could lead to water quality impacts (Hadadin and Tarawneh 2007).

\section{Potential Impacts of Reallocation}

Optimal reallocation is achieved when the Marginal Benefit (MB) is equal across uses, ceteris paribus. The MB of water as a factor of production is the increase in total revenue as a result of one more unit of water. Efficient allocation of water is achieved when the marginal price for each user is equal to the location efficiency price at the user's location (Dinar et al. 1997). That is, the Marginal Cost (MC) of an additional unit of water is the cost of the additional inputs needed to produce that water. The conceptual model will suppose that there are two users ( $\mathrm{A}$ and $\mathrm{B}$ ) and that their economic efficiency can be achieved when $\mathrm{MB}_{\mathrm{A}}=\mathrm{MB}_{\mathrm{B}}$.

\subsection{Conceptual Model}

The model assumes there are two users (A and B), a fixed quantity of water available (Q) and fixed other factors (e.g., technology, water costs, demand) (Fig. 1). Water is currently allocated to $\mathrm{q}^{*}$ where $\mathrm{MB}_{\mathrm{A}}$ less than $\mathrm{MB}_{\mathrm{B}}$. By reallocating $\mathrm{q}_{1}$ from user $\mathrm{A}$ to user $\mathrm{B}$, the economic efficiency goal $\left(\mathrm{MB}_{\mathrm{A}}=\mathrm{MB}_{\mathrm{B}}\right)$ can be achieved (Notice that, at $\left.\mathrm{q}^{*}, \mathrm{MB}=0\right)$ (Fig. 1).

The method is a literature review, hypothetical reallocation based on conclusions found in the literature, and straightforward projections of how reallocation may affect economic activity. Water prices and the marginal benefit to allocate water resources from agriculture to other water users were gleaned from the published literature. The data used to operationalize the conceptual reallocation model came from several studies (Food and Agriculture Organization of the United Nations FAO 2003; United Nations 2003; Beaumont 2002; World Bank 2007). Data from the literature is sufficient to make decisions and to move from "science to solutions" at this point in time. The main goal of water reallocation is to enhance economic efficiency, thereby increasing national development. The following assumptions are taken into consideration:

1. Average annual water availability is constant. Water quantity (surface and ground waters) is assumed to be constant even though, in reality, water availability for the next two decades is not likely to remain constant. The real-life droughts, floods, excessive rainfalls and overexploitation of groundwater could and will, likely affect water availability in the next 20 years. Water availability is assumed to stay constant with respect to reallocation challenges.

2. Water-use technology and efficiencies are constant. The study assumes no innovations or technology that could mitigate water-supply issues. The study assumed that productivity and efficiency levels will be constant.

3. Increasing population. A growing population will put additional pressure on the available water resources. The study assumes population will increase by 3.1\%/year (United Nations 2010).

This study assumes a reallocation of water away from agriculture at $1 \%$ of average total water use per year for the next 20 years for a total reallocation of $20 \%$ by year 20 . . Varying the amount of water reallocated from agriculture to alternate uses will result in proportional changes in GDP\%. The shift in water away from the agriculture sector to other sectors is proposed frequently in the literature. For example, Beaumont (2002) showed that the industrial and service sectors in the Middle East were able to generate upwards of 100 times more wealth for each cubic meter of water than water used by the agriculture sector. In the agriculture sector of 


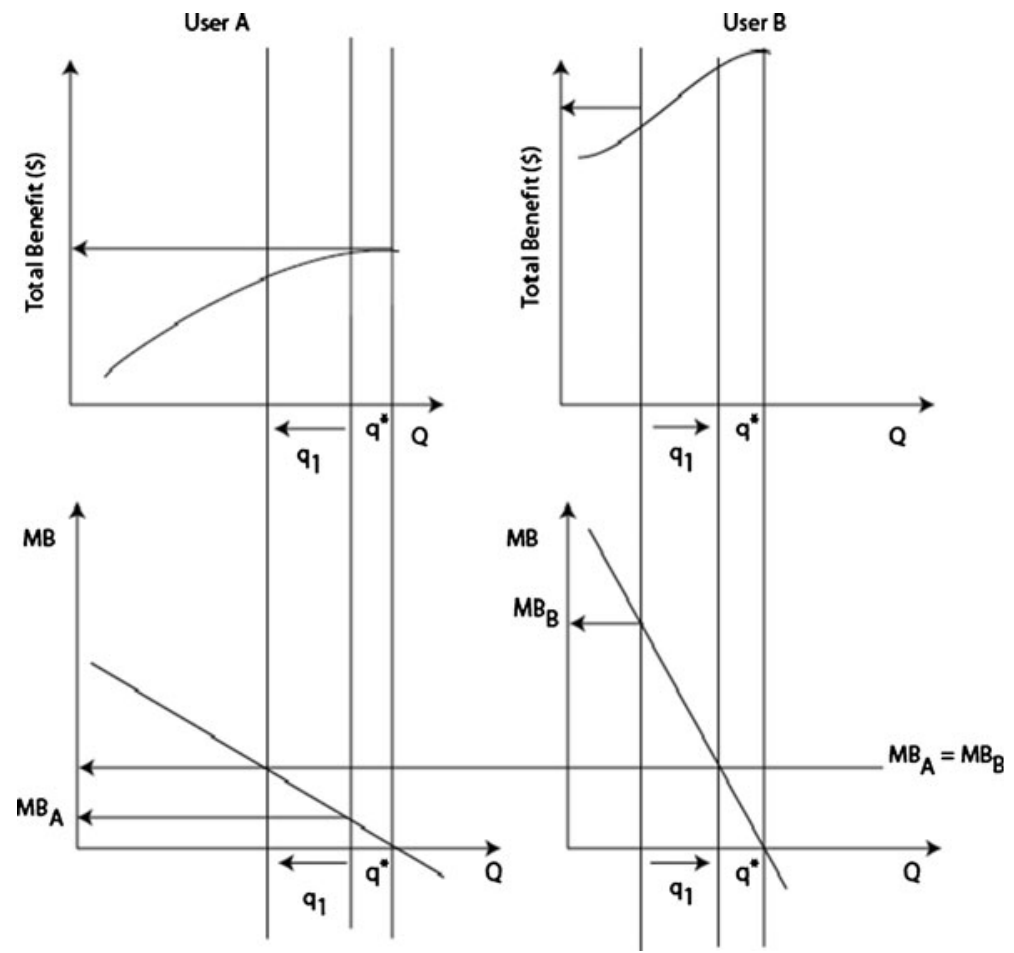

Fig. 1 Conceptual reallocation model for two water users (A and B)

the Middle East, 1 cubic meter of water is capable of generating about US\$2 per year, on average, ranging from US\$0.40 per cubic meter to US\$9.89 per cubic meter (Beaumont 2000).

\subsection{Water Uses (\%)}

Agricultural water use in the FC countries in 2010 accounts for about $66 \%$ of total water use. Water withdrawal for domestic (municipal) and industrial purposes is $26 \%$ and $8 \%$, respectively (Table 2). Without a reallocation plan (without a $20 \%$ reallocation of average total water use from agriculture to other sectors) agricultural use in 2030 will be $59 \%$ of all water resources; municipal and industrial use will be about $32 \%$ and $9 \%$, respectively (Food and Agriculture Organization of the United Nations FAO 2009; United Nations 2003;

Table 2 Total water use (\%) among different sectors and different periods of time (2010 and 2030) in the FC countries

\begin{tabular}{lllll}
\hline & Agriculture (\%) & Municipality (\%) & Industry (\%) & Total (\%) \\
\hline 2010 & 66 & 26 & 8 & 100 \\
2030 (without allocation) & 59 & 29 & 12 & 100 \\
2030 (with allocation) & 46 & 32 & 22 & 100 \\
\hline
\end{tabular}

Food and Agriculture Organization of the United Nations (FAO) (2009), United Nations (2003), World Water Development Report (WWDR) (2003), Beaumont (2002) and World Bank (2007) 
Table 3 Marginal benefit (MB) (\$/m3) among different sectors and different periods of time (2010 and 2030) in the $\mathrm{FC}$ countries

\begin{tabular}{llll}
\hline & Agriculture & Municipality & Industry \\
\hline 2010 & 1.4 & 4 & 3.6 \\
2030 (without reallocation) & 2.6 & 2.9 & 3.1 \\
2030 (with reallocation) & 2.8 & 2.8 & 2.8
\end{tabular}

Food and Agriculture Organization of the United Nations (FAO) (2009), United Nations (2003), Beaumont (2002) and World Bank (2007)

World Water Development Report WWDR 2003; Beaumont 2002; World Bank 2007). With the reallocation plan (with a $20 \%$ reallocation of average total water use from agriculture to other sectors), the total water use in the agricultural, municipal and industrial sectors will be around $46 \%, 32 \%$ and $22 \%$, respectively. Of the $20 \%$ of water allocated away from agriculture, $14 \%$ will be allocated to industrial use and $6 \%$ for municipal use.

\subsection{Marginal Benefit (MB)}

In 2010, the projected MB for water in the agricultural sector was $\$ 1.4$ per cubic meter, the $\mathrm{MB}$ for water in the municipal use was $\$ 4.0$ per cubic meter and the MB for water in the industrial sector was \$3.6 per cubic meter (Food and Agriculture Organization of the United Nations FAO 2009; United Nations 2003; Beaumont 2002; World Bank 2007). With no reallocation in water use among sectors, the MB in 2030 for agricultural, municipal and industrial purposes was estimated by several studies to be $\$ 2.6, \$ 2.9$ and $\$ 3.1$ per cubic meter, respectively (Food and Agriculture Organization of the United Nations FAO 2009; United Nations 2003; Beaumont 2002; World Bank 2007). Efficiency cannot be achieved unless the $\mathrm{MB}$ is equal across the sectors $\left(\mathrm{MB}_{1}=\mathrm{MB}_{2}=\mathrm{MB}_{3}\right.$, where 1,2 and 3 are the agricultural, municipal and industrial sectors, respectively). Marginal benefits for 2030 were estimated by averaging the projected 2030 marginal benefits (from different sources in the literature) for each user. The marginal benefits for the agricultural, municipal and industrial sectors with reallocation were estimated to be $\$ 2.8$ per cubic meter for each sector (Table 3).

\subsection{Change in GDP (\%)}

The study assumes a constant, linear relationship between GDP\% and water use in the feasible range of reallocation amounts. Productivity and efficiency are assumed to be constant. Each sector's contribution to GDP will shift as water is reallocated away from

Table 4 Gross domestic product (GDP) (\%) among different sectors and different periods of time (2010 and 2030 ) in the FC countries

\begin{tabular}{lllll}
\hline & Agriculture (\%) & Municipality (\%) & Industry (\%) & Total (\%) \\
\hline 2010 & 6 & 56 & 22 & 84 \\
2030 (without allocation) & 5 & 62 & 25 & 92 \\
2030 (with allocation) & 4 & 64 & 31 & 99 \\
\hline
\end{tabular}

Adapted from Food and Agriculture Organization of the United Nations (FAO) (2009), United Nations (2003), World Water Development Report (WWDR) (2003), Beaumont (2002) and World Bank (2007) 
agriculture (Table 4). In 2010, $6 \%$ of the total GDP (projection) will be from agriculture, $56 \%$ of GDP from domestic (municipal) use and $22 \%$ from industrial uses(Table 4) (Food and Agriculture Organization of the United Nations FAO 2009; United Nations 2003; World Water Development Report WWDR 2003; Beaumont 2002; World Bank 2007).

In 2030, without water reallocation, the percentage of GDP from agricultural usage will still be low (about $5 \%$ ). The percentage of GDP from the municipal sector will be about $72 \%$ and from the industrial sector about $25 \%$. The percentage of GDP for agricultural, municipal and industrial uses with the allocation plan in 2030 (with a $20 \%$ reallocation of average total water use from agriculture to other sectors) will be $4 \%, 64 \%$ and $31 \%$, respectively (Table 4 ).

\section{Conclusion}

Many studies suggest using water-allocation models to improve economic efficiency and improve water allocation systems. However, there are many challenges associated with water-allocation modeling. Models often are unable to incorporate economic, engineering, political, social and environmental constraints. Water models have addressed some constraints such as transparency, risk and uncertainty, model validations and externalities.

Economic efficiency is the objective of water allocation modeling. Most economists agree, however, that reallocation at the margin to higher-valued uses is a complicated task. In the case of FC water, there is opportunity for considerable non-marginal reallocation. Market mechanisms can be used to achieve a more efficient allocation of the available water resources, but each mechanism has its own set of prerequisites. If water users pay the full marginal cost of water, significant progress toward increasing water-management efficiency could be made.

In 2030 , the reallocation of about $20 \%$ of water from the agricultural sector to other sectors would increase GDP and lead to more efficient use of water. Any similar-sized shift in water use (e.g., $15 \%$ or $30 \%$ ) would have a proportionate impact on GDP and could help alleviate the water-scarcity problem in the FC. Reallocating water from agriculture to other sectors would increase GDP. There is considerable room, well before sophisticated models are needed, for economic progress to be made through water reallocation away from agriculture.

This work has pulled together various elements of water allocation research from the literature to encourage a more comprehensive look at the effect of reallocation in the FC. It does not prescribe a specific model, but encourages FC decision-makers to move forward with incremental shifts in water allocation, based on overwhelming evidence that reallocation will enhance national economic development. The next step is to find ways to overcome the political obstacles to water reallocation.

Open Access This article is distributed under the terms of the Creative Commons Attribution License which permits any use, distribution, and reproduction in any medium, provided the original author(s) and the source are credited.

\section{References}

Abu-Sharar T, Battikhi A (2002) Water resources management under competitive sectoral demand a case study from Jordan. Water International 27(3):364-378

Allan JA (2001) The middle east water question: Hydropolitics and the global economy. I.B. Tauris \& Co. Ltd., London 
Bakker M (1999) Valuing the multiple uses of water. In: Bakker M, Barker R, Meinzen-Dick R, Konradsen F (eds) Multiple uses of water in irrigated areas: A case study from Sri lanka. SWIM paper 8. International Food Policy Research Institute/International Water Management Institute, Colombo, pp 107-119

Beaumont P (2000) The quest for water efficiency-restructuring of water use in the Middle East. Water Air Soil Pollut 123(1-4):551-564

Beaumont P (2002) Water policies for the Middle East in the 21st century: The new economic realities. Water Resources Development 18(2):315-334

Berkoff J (1994) A strategy for managing water in the Middle East and North Africa. World Bank, Washington

Bhattia R, Cesti R, Winpenny J (1995) Water conservation and reallocation: Best practice cases in improving economic efficiency and environmental quality. World Bank-Overseas Development Institute, Joint Study, Washington

Boggess W, Lacewell R, Zilberman D (1993) Economics of water use in agriculture. In: Gerald CA, Zilberman D, Miranowski JA (eds) Agricultural and environmental resource economics. Oxford University Press, New York, pp 319-384

Bontemps C, Couture S (2002) Irrigation water demand for the decision maker. Environmental and Development Economics 7:643-657

Brill E, Hochman E, Zilberman D (1997) Allocation and pricing at the water district level. Am J Agric Econ 79(3):952-963

Dinar A (ed) (2000) "The political economy of water pricing reforms." Journal of development studies. Oxford University Press for the World Bank, New York

Dinar A, Rosegrant M, Meinzen-Dick R (1997) "Water Allocation-Mechanisms Principles and Examples." World Bank Policy Research Working Paper No. 1779

Dudu H, Chumi S (2008) Economics of Irrigation Water Management: A Literature Survey with Focus on Partial and General Equilibrium Models. Policy Research Working Paper. The World Bank Development Research Group, Sustainable Rural and Urban Development Team

Food and Agriculture Organization of the United Nations (FAO) (2003) Review of world water resources by country. Water Reports 23, FAO, Rome, Italy

Food and Agriculture Organization of the United Nations (FAO) (2009) Aquastat water report 34. Retrieved date: 9/3/2010, Available at: http://www.fao.org/nr/water/aquastat/main/index.stm

Hadadin N, Tarawneh Z (2007) Environmental issues in Jordan, solutions and recommendations. Am J Environ Sci 3(1):30-36

Kaiser R, McFarland M (1997) A bibliographic pathfinder on water marketing. Nat Resour J 37:881-907

Mahan R, Horbulyk T, Rowse J (2002) Market mechanisms and the efficient allocation of surface water resources in southern Alberta. Socio-Economic Planning Sciences 36(1):25-49

North DC (1994) Economic performance through time. Am Econ Rev 84(3):359-368

Richards A (2001) Coping with water scarcity: The governance challenge. CGIRS working paper series No. 01-4, Center for global international and regional studies. University of California, Santa Cruz

Sadeque SZ, Turnquist S (1995) Handpump financing issues in Bangladesh: An exploratory study. UNDP/ World Bank Water and Sanitation Program, New Delhi

Spulber N, Sabbaghi A (1994) Economics of water resources. Kluwer Academic Publishers, Norwell

Tietenberg TH (1988) Environmental and resource economics. Scoot, Foresman and Company, Boston

Tsur Y, Dinar A (1997) The relative efficiency and implementation costs of alternative methods for pricing irrigation water. The World Bank Review 11(2):243-262

United Nations Environment Program (UNEP) (2002) Global international waters assessment. Retrieved date: 03/05/2010, Available at: http://www.unep.org/dewa/giwa/about/giwa_leaflet.pdf

United Nations (2003) Sectoral water allocation polices in selected ESCWA members countries: An evaluation of the economic. Social and Drought-related Impact. Economic and Social Commission for Western Asia, New York

United Nations (2010) United Nations salaries: Allowance benefits and job classification (salary scales for staff in general service and related categories). Retrieved date: 11/15/2010, Available at: http:// www.un.org/Depts/OHRM/salaries_allowances/salaries/

World Bank (2007) Making the most of scarcity: Accountability for better water management in the Middle East and North Africa. MENA development report. World Bank, Washington

World Water Development Report (WWDR) (2003) Water for people, water for life. UNESCO and Berghahn, Paris

Yoder R (1981) Non-agricultural uses of irrigation systems: Past experience and implications for planning and design. Paper prepared for agricultural development council. Cornell University, Ithaca 